\title{
ASSESSING THE TRANSFERABILITY OF TRANSPIRATION-USE EFFICIENCY MODELS OF BIOMASS PRODUCTION
}

\author{
Cristián Kremer ${ }^{1,2 *}$, and Claudio Stöckle ${ }^{1}$
}

Transpiration-use efficiency $(w)$, defined as the ratio of biomass produced per unit water transpired, has been used to evaluate crop performance under limited water supply. However, the lack of consistency of $w$ values through different environmental conditions has not allowed, using it as a transferable parameter. Thus, simple approaches have been developed, including: 1) $w=k_{D a} D_{a}^{-1}$ and;2) $w=k_{E t o} E T_{0}^{-1}$ where $k_{D a}$ and $k_{E T o}$ are crop-dependent parameters, with the underlying concept that normalization by $D_{a}$ or $E T_{0}$ would accounts for the effects of climate variations on $w$, while these parameters would be reasonably constant across diverse environments. The objective of this study was to assess the transferability of $k_{D a}$ and $k_{E T o}$ for wheat (Triticum aestivum L.) and maize (Zea mays L.). The scarcity of experimental information and discrepancy of the methodology used, justified the use of a canopy transpiration and photosynthesis model which was developed, tested, and fitted with weather data from eight environmentally different locations to simulate values of $w, k_{D a}$ and $k_{E T o}$. The results indicated that $k_{D a}$ and $k_{E T o}$ were more variable than expected; suggesting that calibration would be desirable. A consistent trend of change of the parameter values as function of $D_{a}$ or $E T_{0}$ was found, which can be represented by mathematical functions, allowing transferring $w, k_{D a}$ and $k_{E T o}$ (maize). In contrast, the $k_{E T o}$ for wheat correlated weakly with $D_{a}$ and $E T_{0}$, but a low overall coefficient of variation $(10 \%)$ allowed using an average value as a reasonable predictor of $w$.

Key words: Transpiration-use efficiency, models of biomass production.

A griculture is challenged by the scarcity of water resources in many regions of the world, problem that is compounded by climate variability and expected to worsen in the future. There is a raising need for tools to evaluate crop productivity as a function of water to better guide development policies and field management practices aimed at producing "more crop per drop".

Mechanistic simulation models of canopy photosynthesis and transpiration appear as suitable tools to evaluate the effect of interacting factors on water-use efficiency and productivity of crops. However, demanding parameterization and computing requirements of these models limit their applicability for long-term analysis that includes multiple species across the globe. As a result, there is a renewed interest in simple, transpiration-based models of crop productivity that can be readily applied to a large number of crop species across the range of climatic conditions where these crops are grown. Although these models were introduced as early as the beginning of the previous century, the experimental determination of the parameters (typically just one parameter) used in the

\footnotetext{
${ }^{1}$ Washington State University, Biological Systems Engineering Department, Pullman, Washington, 99163, USA.

${ }^{2}$ Universidad de Chile, Facultad de Ciencias Agronómicas, Av. Santa Rosa 11315, Santiago, Chile.

*Corresponding author (cristiankremer@gmail.com).

Received: 18 April 2011.
}

Accepted: 4 January 2012. models has been relatively scarce, probably due to the need of measuring crop transpiration for their determination. As a result of scarce experimental information, it is not easy to assess the variability and transferability among locations of the parameters of these simple transpirationbased models.

Attempts to develop simple relationships to predict $w$ for different crops and climates can be traced back to the early $20^{\text {th }}$ century and later (Brigss and Shantz, 1914; Shantz and Piemeisel, 1927; de Witt, 1958; Arkley, 1963; Bierhuizen and Slatyer, 1965; Tanner, 1981; Ritchie, 1983; Tanner and Sinclair, 1983; Steduto and Albrizio, 2005). The underlying assumption has been that the parameters of these relationships are relatively constant across diverse climatic conditions, and assumption that has not been well evaluated.

Early work by Bierhuizen and Slatyer (1965) led the way to the development of a comprehensive physiologically-based description of transpiration use efficiency as follows:

$$
N_{l} T_{l}^{-1}=\Delta C r_{C O 2}^{-1}\left[\left(\rho \varepsilon P_{a}^{-1}\right)\left(D_{l} r_{v}\right)\right]^{-1}
$$

where $N_{l}$ is the net leaf photosynthesis, $T_{l}$ is the leaf transpiration, $\Delta C$ is the $\mathrm{CO}_{2}$ concentration difference between the atmosphere and the $\mathrm{CO}_{2}$ compensation point, $r_{\mathrm{CO} 2}$ is the leaf resistance to $\mathrm{CO}_{2}$ diffusion from the surrounding air into the leaf and into the cells of the chloroplasts, $\rho$ is the density of the air, $\varepsilon$ is the vapor 
to air molecular weight ratio, $D_{l}$ is the vapor pressure difference between the leaf and the surrounding air, $P_{\mathrm{a}}$ is the atmospheric pressure, and $r_{v}$ is the summation of the partial resistances to water vapor flux from the leaf. Bierhuizen and Slatyer (1965) showed that the ratio $N_{l}$ $T_{l}^{-1}$ is determined largely by $D_{l}$ based on the following assumptions: (1) $\Delta C$ is a relatively constant cropdependent parameter, and (2) the $r_{v} r_{\mathrm{CO}_{2}}{ }^{-1}$ ratio is fairly constant in active leaves when the water stress is not severe. The authors redefined Equation [1] in a simpler expression:

where:

$$
N_{l} T_{l}^{-1}=k_{l} D_{l}^{-1}
$$

$$
k_{l}=P_{a} \Delta C r\left[\rho \varepsilon_{C O 2}\right]^{-1}
$$

here $k_{l}$ is considered constant for leaves in a given crop. The authors also argued that $N_{l} T_{l}^{-1}$ should be proportional to canopy $B T^{1}$ (where $B$ is canopy dry matter and $T$ is canopy transpiration) and, therefore, $k_{l}$ could be scaled up to the entire canopy $k_{D a}$ and that $D_{l}$ could be well represented by the air vapor pressure deficit $D_{a}$ since the leaf temperature appear to be within $\pm 2-3{ }^{\circ} \mathrm{C}$ of air temperature. Hence:

$$
w=B T^{-1}=k_{D a} D_{a}^{-1}
$$

where $k_{D a}$ is obtained experimentally as the slope of the linear regression between cumulative biomass and the daily integration of the quotient $T D_{a}^{-1}$.

Tanner and Sinclair (1983) extended the work initiated by Bierhuizen and Slatyer (1965) and Tanner (1981), developing equations to represent biomass production and transpiration of the sunlit and shaded fractions of the canopy, essentially leading to a re-derivation of Equation [4].

Although Equation [4] has been adopted as a reasonable predictor of biomass accumulation (Stöckle et al., 1994; Sinclair and Seligman, 1995), concerns have been raised about the transferability of $k_{D a}$ (Kemanian et al., 2005). These authors argued that $k_{D a}$ is not a "constant" for a crop, but it rather changes with environmental conditions, most noticeable $D_{a}$.

Steduto and Albrizio (2005) presented field data and a discussion of the concept and mechanism of determination of $k_{D a}$, including $\mathrm{C}_{3}$ : chickpea (Cicer arietinum L.), sunflower (Helianthus annuus L.), wheat (Triticum aestivum L.), and $\mathrm{C}_{4}$ : sorghum (Sorghum bicolor (L.) Moench subsp. bicolor) species in one location (Bari, Italy; $41^{\circ} 03^{\prime} \mathrm{N}, 16^{\circ} 52^{\prime} \mathrm{E}, 72 \mathrm{~m}$ a.s.1.). They found that their $k_{D a}$ values had large variability among species and did not match data for the same species from literature. Two explanations to their findings were mentioned: 1) the error introduced by scaling $D_{l}$ to $D_{a}$, especially in low $D_{a}$ conditions where leaf temperature can be several degrees larger than air temperature, and 2) the effectiveness of $D_{a}$ normalization to represent $D_{l}$ since the latter is defined by the transpiration flux, which changes as the physiological stage of the crop changes. They proposed an alternative methodology, similar to the original work by de Witt
(1958), where $w$ is a function of the evaporation rate of a reference condition as:

$$
w=B T^{-1}=k_{E T o} E T_{0}^{-1}
$$

where $E T_{0}$ is the reference crop evaporation computed as proposed by Allen et al. (1998) and $k_{E T o}$ is the slope of the linear regression between cumulative biomass and the daily integration of the quotient $T E T_{0}{ }^{-1}$. Steduto and Albrizio (2005) claim that this method would work better than Equation [4] and that $k_{E T o}$ appeared transferable among different climatic zones. However, this claim was based on limited data and has not been verified.

The main objective of this work was to evaluate the transferability across diverse climatic condition of $k_{D a}$ and $k_{E T o}$ of wheat and maize. However, experimental data allowing the calculation of $k_{D a}$ and $k_{E T o}$ is scarce and does not cover well the wide array of environmental conditions where wheat and maize are grown. In addition, the available data include differences in cultivars, crop management, methods to estimate transpiration, sampling methods for biomass, and other sources of variability and experimental error, making it difficult to evaluate the constancy of the parameters. For that reason, a canopy transpiration and photosynthesis (CTP) model was developed and tested (Kremer, 2006), and used as reference to obtain simulated values of $w, k_{D a}$, and $k_{E T o}$ under variable climatic conditions while crop and soil characteristic were held constant, allowing a more consistent evaluation of the transferability of these parameters.

\section{MATERIALS AND METHODS}

\section{The model}

An hourly time step canopy transpiration and photosynthesis (CTP) model, separating sunlit and shaded fractions of the canopy, was developed as a tool to obtain simulated values of $k_{D a}$ and $k_{E T o}$. The model simulates $\mathrm{C}$ assimilation ( $\mathrm{g} \mathrm{CO}_{2} \mathrm{~m}^{-2}$ ground area), and crop transpiration $\left(\mathrm{kg} \mathrm{H}_{2} \mathrm{O} \mathrm{m}^{-2}\right.$ ground area) in response to climatic conditions, soil and plant water status, and atmospheric $\mathrm{CO}_{2}$ concentration. Transpiration, photosynthesis, stomatal conductance, and plant water uptake are solved simultaneously through an iterative numerical procedure. Daily measurements of global solar radiation, air temperature, air humidity, and wind speed are inputs to the model. Additional inputs include green leaf area index (LAI), maximum crop height, maximum LAI, assimilation rate as a function of intercellular $\mathrm{CO}_{2}$ concentration, stomatal conductance response to air vapor pressure deficit and leaf water potential, and soil characteristics (hydraulic parameters, bulk density, depth, and number and thickness of soil layers). Model performance was tested using meteorological and crop data (wheat and maize) collected at the Conservation and Production 
Research Laboratory, Bushland (3511' N, 102 $06^{\circ}$ W; elevation $1170 \mathrm{~m}$ a.s.1.), Texas, USA, indicating the suitability of the model for the application presented in this research. A more detailed description of the CTP model and parameters for the simulation of wheat and maize transpiration-use efficiency is presented in Kremer (2006). For this study, soil water content, LAI, crop height, and crop parameters for photosynthesis and stomatal conductance were held constant during the entire simulation period at all the locations. Thus, only daily weather was variable.

\section{Meteorological data}

To generate a highly diverse set of conditions, daily weather data from eight locations were selected. The data were composed of daily measurements of global solar radiation $\left(\mathrm{MJ} \mathrm{m}^{-2} \mathrm{~d}^{-1}\right)$, maximum and minimum air temperature $\left({ }^{\circ} \mathrm{C}\right)$, maximum and minimum air relative humidity, and average wind speed $\left(\mathrm{m} \mathrm{s}^{-1}\right)$, encompassing the period day of the year (DOY) 120 through 239 for a year selected at random in the following locations: Concepcion del Uruguay $\left(32^{\circ} 28^{\prime} \mathrm{S}, 58^{\circ} 16^{\prime} \mathrm{W}\right.$; elevation $20 \mathrm{~m}$ a.s.l.), Argentina; Landriano $\left(45^{\circ} 18^{\prime} \mathrm{N}, 9^{\circ} 15^{\prime} \mathrm{E}\right.$; elevation 78 $\mathrm{m}$ a.s.1.), Italy; Temple ( $31^{\circ} 7^{\prime} \mathrm{N}, 9^{\circ} 4^{\prime} \mathrm{W}$; elevation $208 \mathrm{~m}$ a.s.1.), Texas, USA; Pullman $\left(46^{\circ} 45^{\prime} \mathrm{N}, 117^{\circ} 1^{\prime}\right.$ W; elevation $756 \mathrm{~m}$ a.s.1.), Washington, USA; Prosser $\left(46^{\circ} \mathrm{N}, 119^{\circ} 7^{\prime} \mathrm{W}\right.$; elevation $380 \mathrm{~m}$ a.s.l.), Washington, USA; Ankara (40 $7^{\prime}$ N, $32^{\circ} 59^{\prime}$ E; elevation 948 m a.s.l.), Turkey; Aleppo (36 $1^{\prime}$ ' N,37 $38^{\circ}$ ' E; elevation 430 m a.s.1.), Syria; and DOY 166 through 239 for Maricopa (33 ${ }^{\circ} 49^{\prime}$ $\mathrm{N}, 112^{\circ} 1^{\prime} \mathrm{W}$; elevation $359 \mathrm{~m}$ a.s.1.), Arizona, USA. The main climatic characteristics of the selected period in the eight locations are presented in Table 1.

\section{Determination of $\boldsymbol{k}_{D a}$ and $\boldsymbol{k}_{E T o}$}

Daily transpiration and photosynthesis for wheat and maize were simulated for all locations using the CTP model and assuming well-developed and unstressed crops. The parameters $k_{D a}\left(\mathrm{~g} \mathrm{CO}_{2} \mathrm{~kg}^{-1} \mathrm{H}_{2} \mathrm{O} \mathrm{kPa}\right)$ and $k_{E T o}\left(\mathrm{~g} \mathrm{CO}_{2}\right.$ $\mathrm{m}^{-2}$ ) were estimated as the slope of the linear regression between cumulative photosynthesis and the accumulation of the transpiration to daytime $D_{a}$ quotient (Tanner, 1981; Condon et al., 1993) and transpiration to $E T_{0}$ quotient (Steduto and Albrizio, 2005), respectively. Calculations of the parameters were done for moving 15-d intervals, shifted by $5 \mathrm{~d}$ throughout the 120 -d period. Daily $E T_{0}$ calculation was carried out as proposed by Allen et al. (1998).

\section{RESULTS AND DISCUSSION}

As was expected simulated $w$ values for 15 -d periods across eight locations were highly variable (Table 2), with coefficient of variation of $25 \%$ and $18 \%$ for wheat and maize, respectively, with the known implication that $w$ values determined experimentally in one location may not be readily transferable to another. Normalization of $w$ by $D_{a}$ Equation [4] or $E T_{0}$ Equation [5] is expected to account for weather variability, with the parameters $k_{D a}$ or $k_{E T o}$ remaining reasonable constant. However, as shown in Table $2 k_{D a}$ and $k_{E T o}$ (maize) present more variability than desirable for transferring values derived in one location to another with $k_{D a}$ variability being greater than that of $k_{E T o}$.

As pointed out by Tanner (1981) and Steduto and Albrizio (2005), a drawback associated with $D_{a}$ normalization is usually related to the degree of error introduced on the assumption that $D_{a}$ is a fair

Table 2. Mean (x), standard deviation (sd), number of data (n), and coefficient of variation (CV) for simulated values of transpiration-use efficiency $(w)$, and the crop parameters $k_{D a}$ and $k_{E T o}$ from eight locations.

\begin{tabular}{lcccc}
\hline Parameters & $\mathrm{n}$ & $\mathrm{x}$ & $\mathrm{sd}$ & $\mathrm{CV}(\%)$ \\
\hline w, $\mathrm{g} \mathrm{CO}_{2} \mathrm{~kg}^{-1} \mathrm{H}_{2} \mathrm{O}$ & & & & \\
$\quad$ Wheat & 159 & 10.71 & 2.69 & 25.09 \\
$\quad$ Maize & 159 & 17.50 & 3.07 & 17.53 \\
$\quad \begin{array}{l}k_{D a}, \mathrm{~g} \mathrm{CO}_{2} \mathrm{~kg}^{-1} \mathrm{H}_{2} \mathrm{O} \mathrm{Pa} \\
\quad \text { Wheat }\end{array}$ & 159 & 15.99 & 4.35 & 27.21 \\
$\quad$ Maize & 159 & 27.70 & 9.66 & 34.88 \\
$\quad$ kTo, $\mathrm{g} \mathrm{CO}_{2} \mathrm{~m}^{-2}$ & & & & \\
$\quad$ Wheat & 159 & 55.87 & 5.68 & 10.16 \\
$\quad$ Maize & 159 & 94.37 & 16.79 & 17.80 \\
\hline
\end{tabular}

Table 1. Mean ( $x$ ) and standard deviation (sd) of weather data from eight locations and selected periods.

\begin{tabular}{|c|c|c|c|c|c|c|c|c|c|}
\hline \multicolumn{2}{|c|}{ Variables } & \multirow{2}{*}{$\begin{array}{c}\text { Concepción } \\
27.8\end{array}$} & \multirow{2}{*}{$\begin{array}{c}\text { Landriano } \\
26.0\end{array}$} & \multirow{2}{*}{$\begin{array}{c}\text { Temple } \\
31.2\end{array}$} & \multirow{2}{*}{$\begin{array}{c}\text { Pullman } \\
22.6\end{array}$} & \multirow{2}{*}{$\begin{array}{c}\text { Prosser } \\
27.0\end{array}$} & \multirow{2}{*}{$\begin{array}{c}\text { Ankara } \\
27.9\end{array}$} & \multirow{2}{*}{$\begin{array}{c}\text { Aleppo } \\
34.7\end{array}$} & \multirow{2}{*}{$\begin{array}{c}\text { Maricopa } \\
38.9\end{array}$} \\
\hline$T_{\max }$ & $\mathrm{x}$ & & & & & & & & \\
\hline & sd & 4.0 & 4.7 & 3.3 & 6.8 & 6.3 & 6.1 & 4.9 & 2.5 \\
\hline \multirow[t]{2}{*}{$T_{\min }$} & $\mathrm{x}$ & 16.9 & 14.2 & 20.6 & 8.4 & 9.3 & 14.3 & 17.5 & 24.3 \\
\hline & $\mathrm{sd}$ & 3.3 & 3.4 & 2.9 & 4.2 & 4.2 & 4.7 & 5.3 & 2.1 \\
\hline \multirow[t]{2}{*}{$S_{R}$} & $\mathrm{x}$ & 21.5 & 22.5 & 21.1 & 23.3 & 25.7 & 21.1 & 27.2 & 27.6 \\
\hline & sd & 7.8 & 6.5 & 5.8 & 5.9 & 5.2 & 4.4 & 2.3 & 3.6 \\
\hline \multirow{2}{*}{$R H_{\max }$} & $\mathrm{x}$ & 99.7 & 85.5 & 92.0 & 81.4 & 61.7 & 63.1 & 67.4 & 78.7 \\
\hline & sd & 2.2 & 21.4 & 6.3 & 12.4 & 14.5 & 14.3 & 15.0 & 17.0 \\
\hline \multirow{2}{*}{$R H_{\min }$} & $\mathrm{x}$ & 64.8 & 46.7 & 47.6 & 32.8 & 43.4 & 31.7 & 25.7 & 25.1 \\
\hline & $\mathrm{sd}$ & 13.3 & 21.3 & 12.9 & 13.0 & 9.2 & 15.3 & 7.2 & 11.2 \\
\hline \multirow[t]{2}{*}{ Wind } & $\mathrm{x}$ & 3.0 & 1.2 & 2.7 & 2.1 & 1.5 & 1.8 & 4.8 & 2.2 \\
\hline & sd & 1.3 & 0.6 & 1.1 & 1.0 & 0.5 & 0.7 & 1.9 & 0.5 \\
\hline \multirow[t]{2}{*}{$E T_{0}$} & $\mathrm{x}$ & 4.3 & 4.3 & 5.3 & 4.4 & 4.8 & 5.0 & 9.0 & 7.7 \\
\hline & sd & 1.5 & 1.2 & 1.3 & 1.2 & 1.1 & 1.3 & 2.0 & 1.2 \\
\hline \multirow{2}{*}{$D_{a}$} & $\mathrm{x}$ & 0.8 & 1.0 & 1.5 & 1.1 & 1.3 & 1.8 & 2.6 & 3.2 \\
\hline & $\mathrm{sd}$ & 0.3 & 0.4 & 0.6 & 0.6 & 0.6 & 0.8 & 0.8 & 0.9 \\
\hline
\end{tabular}

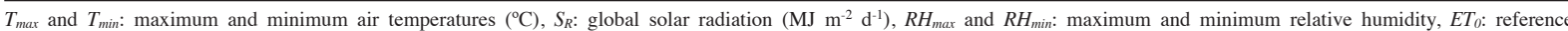
evapotranspiration $\left(\mathrm{mm} \mathrm{d}^{-1}\right), D_{a}$ : day time air vapor pressure deficit $\left(\mathrm{k}_{\mathrm{Pa}}\right)$ estimated as: $D_{a}=2 / 3 \mathrm{e}_{\mathrm{s}}\left(T_{\max }\right)\left(1-R_{\min }\right)$, where $e_{s}\left(T_{\max }\right)$ is the saturation vapor pressure of the air in $\mathrm{kPa}$ at maximum air temperature. 
representation of $D_{l}$, especially in humid environments. In these environments, transpiration rate is expected to be lower, and as a result leaf temperature should increasingly depart from air temperature making $D_{l}$ larger than $D_{a}$. To test this assumption, the values of $k_{D a}$ obtained in environments with $D_{a}$ less than $1 \mathrm{kPa}$ were not included in the coefficient of variation (CV) analysis. Some improvement on $\mathrm{CV}$ was obtained for both crops however the variability still remained (wheat: $18.75 \%$, and maize: $26.18 \%$ ).

Figures 1 and 2 present $w$ as a function of the average $D_{a}$ and $E T_{0}$, of each corresponding 15-d interval. Both figures show that $w$ is not constant across environments characterized by $D_{a}$ and $E T_{0}$, and has an important non-linear response to $D_{a}$ and $E T_{0}$ (Abbate et al., 2004; Kemanian et al., 2005). Fitted power equations appear good estimators of $w$, with $D_{a}$ explaining $94 \%$ and $90 \%$ of the $w$ variability for wheat and maize, respectively, and $E T_{0}$ explaining $89 \%$ and $72 \%$, respectively. The dispersion around the fitted lines represents variability due to climate that is not accounted for $D_{a}$ or $E T_{0}$. This effect of other weather variables is less important with $D_{a}$ and $E T_{0}$ greater than $2 \mathrm{kPa}$ and $7 \mathrm{~mm} \mathrm{~d}^{-1}$, respectively.

Figure 3 reaffirms that the variability in Table 2 is not random, but can be explained to a large extent when $k_{D a}$ values are plotted vs. $D_{a}$ or $E T_{0}$. A linear equation was fitted to the $k_{D a}$ values and included in the figure. It seems that $D_{a}$ was able to explain $k_{D a}$ variability better than $E T_{0}$, which presented a larger scattering, particularly for wheat. These results confirm that: 1) $k_{D a}$ is not a constant value and, 2) $k_{D a}$ increases when $D_{a}$ and $E T_{0}$ increases.
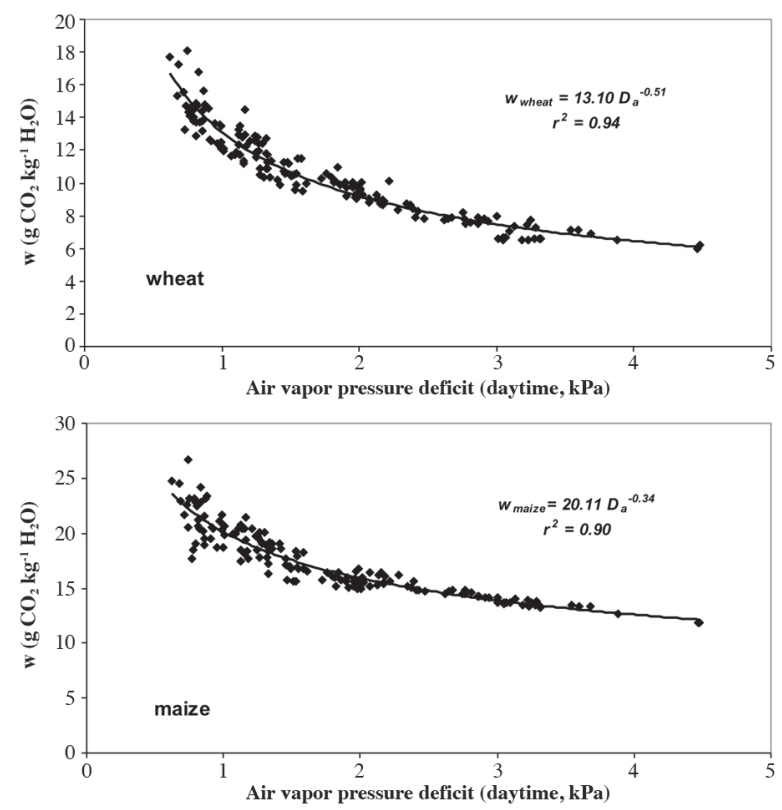

Figure 1. Transpiration use efficiency $\left(w, \mathrm{~g} \mathrm{CO}_{2} \mathrm{~kg}^{-1} \mathrm{H}_{2} \mathrm{O}\right)$ as a function of the air water vapor pressure deficit (daytime, $\mathrm{kPa}$ ) for wheat and maize.
The significant conclusion is that the use of Equation [4] to estimate $w$ has to considerer local calibration of $k_{D a}$ to be transferable. The linear response obtained for $k_{D a}$ should facilitate transferability through field calibration based on a few points across the environmental range. The fitted linear equations included in each figure, can be used as $k_{D a}$ estimators for climatic conditions characterized by different $D_{a}$ or $E T_{0}$.

In an attempt to explain $k_{E T o}$ variability, $k_{E T o}$ values were plotted vs. $D_{a}$ and $E T_{0}$ (Figure 4). Fitted linear equations are included in the Figure 4, which shows that $k_{E T o}$ variation in wheat does not correlate well with variations in climatic conditions represented by $D_{a}$ or $E T_{0}$. However the relatively low $\mathrm{CV}$ and standard deviation (sd) determined that a mean value of $55.87\left(\mathrm{~g} \mathrm{CO}_{2} \mathrm{~m}^{-2}\right)$ can be used as a constant regardless of the climatic environment, supporting the view of Steduto and Albrizio (2005). Nevertheless, some response of $k_{E T o}$ for wheat when the $E T_{0}$ gradient is increasing was observed (Figure 4), suggesting some benefit of using the fitted equation in situations with high evaporative demand.

A different scenario was found in maize (Table 2). Figure 4 shows that $k_{E T o}$ (maize) did not correlate well with variations in $D_{a}$, and that the variability was better explained by $E T_{0}$, although $E T_{0}$ alone was not able to account for the entire variability due to weather. It can be concluded that $k_{E T o}$ is not a constant and, therefore, experimental values cannot be transferred among locations with different climate. The linear equation presented here to estimate $k_{E T o}$ as function of $E T_{0}$ for maize should be taken as first approximation to overcome the transferability problem.
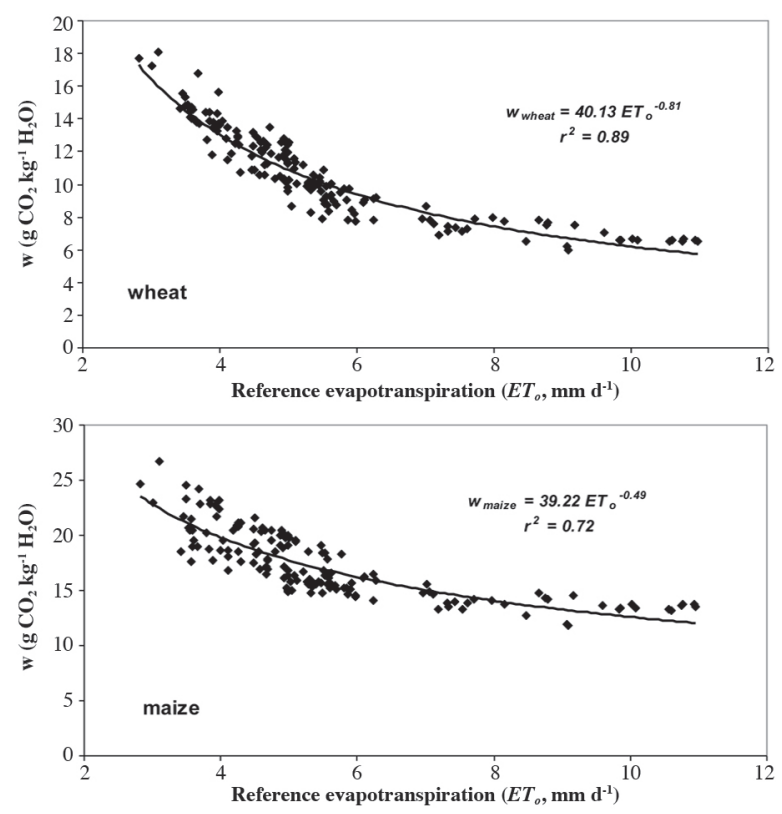

Figure 2. Transpiration use efficiency $\left(w, \mathrm{~g} \mathrm{CO}_{2} \mathrm{~kg}^{-1} \mathrm{H}_{2} \mathrm{O}\right)$ as a function of reference evapotranspiration $\left(E T_{0}, \mathrm{~mm} \mathrm{~d}^{-1}\right)$ for wheat and maize. 

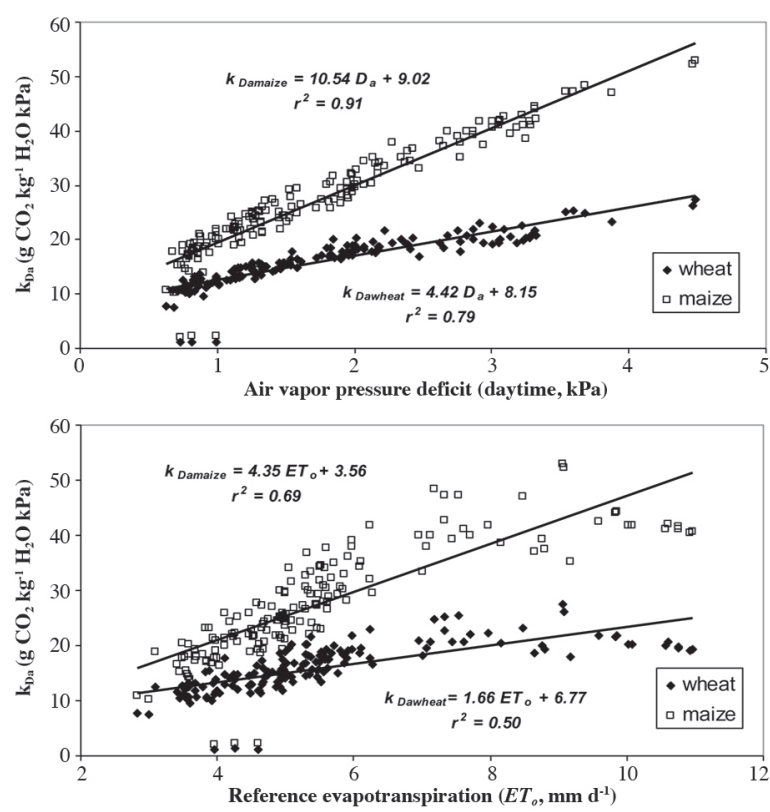

Figure 3. Variability of the crop dependant parameter $k_{D a}\left(\mathrm{~g} \mathrm{CO}_{2} \mathrm{~kg}^{-1} \mathrm{H}_{2} \mathrm{O}\right.$ $\mathrm{kPa})$ as a function of the daytime vapor pressure deficit $\left(D_{a} ; \mathrm{kPa}\right)$, and the reference evapotranspiration $\left(E T_{0}, \mathrm{~mm} \mathrm{~d}^{-1}\right)$ for wheat and maize.
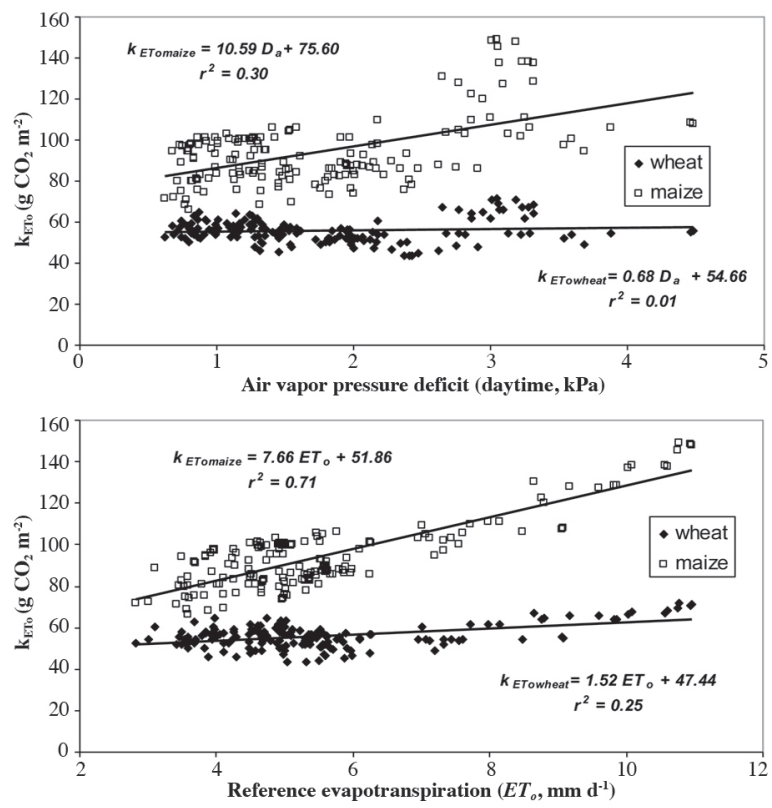

Figure 4. Variability of the crop dependant parameter $k_{E T o}\left(\mathrm{~g} \mathrm{CO}_{2} \mathrm{~m}^{-2}\right)$ as a function of the daytime vapor pressure deficit $\left(D_{a} ; \mathrm{kPa}\right)$, and the reference evapotranspiration $\left(E T_{0}, \mathrm{~mm} \mathrm{~d}^{-1}\right)$ for wheat and maize.

\section{CONCLUSIONS}

The simulation results showed as was expected that $w$ is not constant across climatic environments, so that values determined in one location cannot be readily transferred to another. However, $w$ as a function of $D_{a}$ and $E T_{0}$ was well described by a power function, with $D_{a}$ explaining
$94 \%$ and $90 \%$ of the $w$ variability for wheat and maize, respectively, and $E T_{0}$ explaining $89 \%$ and $72 \%$, respectively. The dispersion around the fitted lines was much lower with $D_{a}$ and $E T_{0}$ greater than $2 \mathrm{kPa}$ and $7 \mathrm{~mm} \mathrm{~d}^{-1}$, respectively.

Normalization of the $\mathrm{k}_{\mathrm{Da}}$ and $k_{E T o}$ parameters of two simple transpiration-use efficiency models by $D_{a}$ and $E T_{0}$ was not able to properly account for the effect of weather variability, resulting in parameters still too variable to be readily transferred across locations for both wheat and maize.

It was found that the transferability of these parameters can be dramatically improved when they are plotted against $D_{a}$ (in the case of $k_{D a}$ ) or $E T_{0}$ (in the case of $k_{E T O}$ ), with linear functions describing well the relations and explaining $79 \%$ and $91 \%$ of $k_{D a}$ variability for wheat and maize, and $71 \%$ of $k_{E T O}$ variability for maize. The $k_{E T O}$ for wheat correlated weakly with $E T_{0}$, explaining only $25 \%$ of its variability. However, the overall coefficient of variation of this parameter across eight locations was about $10 \%$, so that the use of a constant $k_{E T o}$ value is not unreasonably, although is not a perfect solution.

The simulation-based equations presented here are offered as a first approximation to overcome the spatial transferability of $w, k_{D a}$, and $k_{E T o}$, but field validation will be required before adoption is recommended.

Comprobando la transferibilidad de modelos para la producción de biomasa basados en la eficiencia del uso de la transpiración. Eficiencia del uso de la transpiración $(w)$, definida como la relación entre biomasa producida por unidad de agua transpirada, se ha utilizado para evaluar productividad bajo condiciones limitadas de agua. Sin embargo, la falta de consistencia de valores $w$ bajo condiciones climáticas distintas no ha permitido su uso como parámetro transferible. Consecuentemente, aproximaciones simples han sido desarrolladas, incluyendo: 1) $w=k_{D a} D_{a}^{-1} \mathrm{y}$;2) $w=k_{E T o} E T_{0}^{-1}$ donde $k_{D a} \mathrm{y}$ $k_{E T o}$ son parámetros dependientes del cultivo, y sustentado en que la normalización por $D_{a}$ o $E T_{o}$ absorbería el efecto del clima en la determinación de $w$, mientras que estos parámetros se mantendrían razonablemente constantes. El objetivo de este estudio fue determinar la transferibilidad de $k_{D a}$ y $k_{E T o}$ para su uso en trigo (Triticum aestivum L.) y maíz (Zea mays L.). La escasez de información experimental y metodologías usadas, justificó el uso de un modelo para estimar transpiración y fotosíntesis, el cual fue desarrollado y probado con datos de ocho regiones climáticamente distintas para simular valores de $k_{D a}$ y $k_{E T o}$. Los resultados indicaron que estos parámetros poseían mayor variabilidad de la esperada, sugiriendo que una calibración previa sería necesaria. Además, el cambio de estos parámetros como función de $D_{a}$ o $E T_{0}$ tiene una tendencia consistente, representable por funciones matemáticas, permitiendo transferir $w, k_{D a}$ y $k_{E T o}$ (maíz). 
Por otro lado, valores de $k_{E T o}$ en trigo se correlacionaron débilmente con $D_{a}$ y $E T_{0}$, pero un bajo coeficiente de variación (10\%) permitiría el uso de un valor promedio como un predictor razonable de $w$.

Palabras clave: eficiencia en el uso de la transpiración, modelos de producción de biomasa.

\section{LITERATURE CITED}

Abbate, P.E., J.L. Dardanelli, M.G. Cantero, M. Maturano, R.J.M. Melchiori, and E.E. Suero. 2004. Climatic and water availability effects on water-use efficiency in wheat. Crop Science 44:474483.

Allen, R.G., L.S. Pereira, D. Raes, and M. Smith. 1998. Crop evapotranspiration: Guidelines for computing crop water requirements. Irrigation and Drainage Paper 56. FAO, Rome, Italy.

Arkley, R.J. 1963. Relationships between plant growth and transpiration. Hilgardia 34:559-584.

Bierhuizen, J.F., and R.O. Slatyer. 1965. Effect of atmospheric concentration of water vapor and $\mathrm{CO}_{2}$ in determining transpirationphotosynthesis relationships of cotton leaves. Agricultural Meteorology 2:259-270.

Brigss, L.J., and H.L Shantz. 1914. Relative water requirement of plants. Journal of Agricultural Research 3:1-63.

Condon, A.G., R.A. Richards, and G.D. Farquhar. 1993. Relationships between carbon isotope discrimination, water use efficiency and transpiration efficiency for dryland wheat. Australian Journal of Agricultural Research 44:1693-1711.

de Witt, C.T. 1958. Transpiration and crop yield. Versl. Landbouwk.
Onderz. 64.6. Institute of Biological and Chemical Research on Field Crops and Herbage, Wageningen, The Netherlands.

Kemanian, A.R., C.O. Stöckle, and D.R. Huggins. 2005. Transpiration-use efficiency of barley. Agricultural and Forestal Meteorology 130:1-11.

Kremer, C. 2006. Evaluating simple transpiration-based models of crop productivity. Ph.D. diss. Washington State University, Department of Biological Systems Engineering, Pullman, Washington, USA.

Ritchie, J.T. 1983. Efficient water use in crop production: Discussion on the generality of relations between biomass production and evapotranspiration. p. 29-44. In Taylor H.M. et al. (eds.) Limitations to efficient water use in crop production. ASA, CSSA, SSSA, Madison, Wisconsin, USA.

Shantz, H.L., and L.N. Piemeisel. 1927. The water requirement of plants at Akron, Colorado. Journal of Agricultural Research 34:1093-1190.

Sinclair, T.R., and N.G. Seligman. 1995. Global environmental change and simulated forage quality of wheat in non stressed Conditions. Field Crops Research 40:19-27.

Steduto, P., and R. Albrizio. 2005. Resource use efficiency of field-grown sunflower, sorghum, wheat and chickpea. II. Water use efficiency and comparison with radiation use efficiency. Agricultural and Forestal Meteorology 130:269-281.

Stöckle, C.O., S. Martin, and G.S. Campbell. 1994. CropSyst, a cropping systems model: water/nitrogen budgets and crop yield. Agricultural Systems 46:335-359.

Tanner, C.B. 1981. Transpiration efficiency of potato. Agronomy Journal 73:59-64.

Tanner, C.B., and T.R. Sinclair. 1983. Efficient water use crop production: Research or re-search? p. 1-27. In Taylor, H.M. et al. (eds.) Limitations to efficient water use in crop production. ASA, CSSA, SSSA, Madison, Wisconsin, USA. 